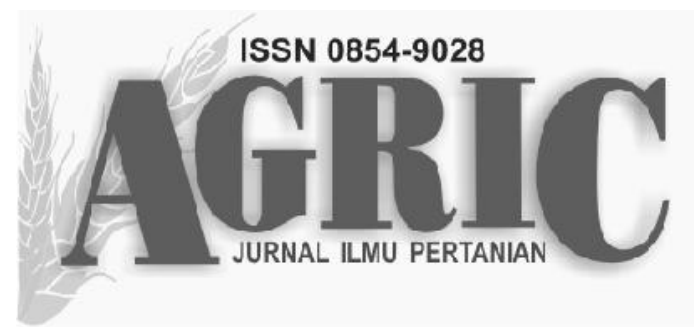

Fakultas Pertanian dan Bisnis Universitas Kristen Satya Wacana JI. Diponegoro 52-60 SALATIGA 50711 - Telp. 0298-321212 ext 354 email: agric_fpb@yahoo.co.id, website: ejournal.uksw.edu/agric

\title{
PARTISIPASI MASYARAKAT \\ DALAM PROGRAM BANTUAN LANGSUNG PAKAN SAPI PERAH DI DUSUN WATES DESA SUMOGAWE KECAMATAN GETASAN
}

\author{
COMMUNITY PARTICIPATION \\ IN DAIRY CATTLE FEED DIRECT ASSISTANCE PROGRAM \\ AT WATES SUMOGAWE VILLAGE GETASAN SUB-DISTRICT \\ SEMARANG REGENCY
}

\author{
Ayuk Mutiara Saraswati \\ Mahasiswa Program Studi Agribisnis Fakultas Pertanian dan Bisnis Universitas Kristen Satya Wacana \\ J1. Diponegoro 52-60 Salatiga \\ Tinjung Mary Prihtanti \\ Program Studi Agribisnis Fakultas Pertanian dan Bisnis Universitas Kristen Satya Wacana \\ J1. Diponegoro 52-60 Salatiga \\ tinjung.murjono@gmail.com
}

Diterima 30 Juni 2015, disetujui 10 Agustus 2015

\begin{abstract}
The purpose of the study to know the process and the level of participation from the planning to the implementation of the program of direct assistance to strengthen the animal feed dairy cows; and to determine the factors driving and inhibiting factors of community participation in strengthening Assistance Program Dairy Cattle Feeding, by taking the research location in the Wates, Sumogawe Village, District Getasan, Semarang regency. The study revealed that: (1) Public participation at the program includes involvement in the stage of socialization activities; implementation; monitoring; and evaluation activities; (2) Participation of farmers in the form of aspiration in determining the location, involvement given in the implementation of activities, participation forage material, and social participation that is mutually assist in the implementation of the program and solve problems together; (3) The level of public participation in the program when compared with eight rungs Arnstein only until consulting level; (4) The driving factors for community participation in the Strengthening Aid Dairy Cattle Feeding Program a) The assistance provided free of charge, and the necessary requirements are not difficult; $b$ ) The program in accordance with the needs of the community members; $c$ ) extension workers willing to provide regular guidance to farming group; d) the location was available forage; e) Intertwined good cooperation and communication relations between farmer with field officers. Factors inhibiting a) in evaluating the feeling lazy in preparing reports on the production of milk; b) farmer with higher avoid to join because already have a high income; and c) limited quantity of assistance was raised the existence of envy.
\end{abstract}

Keywords: community, participation, dairy, cattle, evel of public participation, Getasan 


\section{PENDAHULUAN}

Untuk meningkatkan produktivitas ternak khususnya sapi potong dan sapi perah, Kementerian Pertanian Direktorat Jenderal Peternakan dan Kesehatan Hewan melakukan upaya pengembangan pakan nasional. Salah satu kegiatan terobosan yang dilakukan untuk membantu peternak dalam melakukan usaha sapi perah adalah dengan pemberian bantuan pakan konsentrat yang berkualitas kepada ternak. Bentuk daripada pakan konsentrat sendiri merupakan pakan yang sudah jadi. Menurut Direktorat Jenderal Peternakan dan Kesehatan Hewan kementrian Pertanian Republik Indonesia (2013), tujuan utama program ini adalah untuk meningkatkan produksi susu 1 sampai 2 liter per ekor per hari. Hasil evaluasi Direktorat Pakan menunjukkan bantuan pakan konsentrat ber-kualitas baik dengan protein kasar minimal 16 persen dan TDN (total digestible nutrients) minimal 70 persen selama 5 bulan menunjukkan hasil yang cukup signifikan yakni terjadi peningkatan produksi susu secara rata-rata sebesar 1,53 liter/hari, meningkatkan kualitas Total Solid (TS) susu secara rata-rata sebesar 0,49 persen, dan meningkatkan pendapatan peternak secara ratarata sebesar Rp13.378,-.

Berdasarkan data Dinas Peternakan Provinsi Jawa Tengah, di wilayah Kecamatan Getasan, Kabupaten Semarang, Provinsi Jawa Tengah pada tahun 2014 terdapat 17 kelompok tani yang menerima bantuan program penguatan pakan sapi perah. Salah satu kelompok tani sapi perah yang mendapatkan bantuan yakni kelompok tani Barokah Abadi yang bertempat di Dusun Wates, Desa Sumogawe, Kecamatan Getasan. Bantuan ini dimulai pada tahun 2013 dan masih berlanjut hingga sekarang. Bantuan program penguatan pakan sapi perah diberikan karena rendahnya produksi susu peternak sapi perah yang sekitar 8 liter per ekor per hari dan skala kepemilikan ternak rata-rata masih 2-3 ekor. Rendahnya tingkat produksi dan produktivitas sapi perah salah satu penyebabnya adalah masih rendahnya penggunaan pakan yang berkualitas saat ini. Rata-rata pakan konsentrat yang digunakan oleh peternak masih dibawah SNI dimana nilai protein kasar masih sekitar 14 persen sedangkan sesuai SNI disyaratkan untuk sapi laktasi kadar protein kasar minimal
16 persen. Hal ini disebabkan karena daya beli peternak pada pakan yang berkualitas, sangat rendah terkait dengan harga jual susu yang masih rendah, sehingga antara biaya produksi dan harga jual susu masih belum menguntungkan peternak.

Dalam kondisi seperti ini, pemerintah Provinsi melalui Dinas Peternakan mencoba melakukan peningkatan usaha peternakan sapi perah dengan memberikan bantuan penguatan pakan sapi perah untuk meningkatkan kualitas pakan. Tujuan program penguatan pakan ternak sapi perah tersebut yakni meningkatkan produksi susu sapi perah dengan pemberian bantuan pakan yang sesuai dengan standar dan kebutuhan hidup ternak sehingga sapi perah akan mendapatkan pakan yang berimbang dan berkualitas, dan meningkatkan pendapatan peternak dengan adanya penambahan produksi susu dan peningkatan kualitas susu. Evaluasi pelaksanaan bantuan langsung pakan sapi perah tahun 2013 menunjukkan hasil yang nyata yaitu meningkatkan produksi susu sebanyak 0,5 - 3 liter per ekor per hari, meningkatkan Total Solid (TS) rata-rata sebanyak 0,49 persen dan meningkatkan pendapatan Rp. 13.000,per peternak per hari. Menurut Sudono et al (2003 dalam Mardiningsih, 2007) bahwa konsentrat diberikan sebelum pemerahan supaya selama pemerahan sapi tenang. Dengan adanya program tersebut diharapkan masyarakat ikut berpatisipasi langsung guna peningkatan produksi susu dan peningkatan kemampuan reproduksi secara optimal, yaitu mampu melahirkan satu pedet setiap tahunnya. Pada akhirnya program ini diharapkan dapat meningkatkan pendapatan para peternak sapi perah.

Program tersebut membutuhkan partisipasi dari masyarakat peternak karena pemerintah hanya menyediakan konsentrat pada takaran tertentu yang dicampurkan pada hijauan pakan. Partisipasi masyarakat merujuk pada keikutsertaan masyarakat dalam aktivitas pembangunan yang didasari motifmotif dan keyakinan akan nilai-nilai tertentu yang dihayati masyarakat. Secara garis besar, partisipasi dapat dibedakan atas: (1) partisipasi pasif, yaitu masyarakat dilibatkan dalam tindakan yang telah dipikirkan, dirancang, dan dikontrol oleh orang lain; dan (2) partisipasi aktif, yakni proses pembentukan kekuatan untuk keluar dari perma- 
salahan yang dihadapi (Basuno et al., 2005). Tahap partisipasi meliputi perencanaan, pelaksanaan, pemanfaatan, serta evaluasi.

Tujuan studi ini yakni untuk mengetahui bagaimana proses partisipasi masyarakat sejak perencanaan hingga pelaksanaan terhadap program bantuan langsung penguatan pakan ternak sapi perah; mengetahui tingkat partisipasi masyarakat dalam Program Bantuan Penguatan Pakan Sapi Perah tersebut; serta mengetahui faktor pendorong dan faktor penghambat partisipasi masyarakat dalam Program Bantuan Penguatan Pakan Sapi Perah, dengan mengambil lokasi penelitian di Dusun Wates, Desa Sumogawe, Kecamatan Getasan, Kabupaten Semarang.

\section{METODE PENELITIAN}

Studi lapangan ini merupakan studi kasus pada anggota kelompok tani sapi perah penerima bantuan penguatan pakan tahun 2014 di Dusun Wates, Desa Sumogawe, Kecamatan Getasan, Kabupaten Semarang. Desa Sumogawe merupakan salah satu desa yang berada di Kecamatan Getasan dan juga merupakan desa yang mempunyai potensi terbesar pada produksi susu sapi perah, dengan memiliki \pm 10 kelompok tani ternak yang tersebar di berbagai dusun, serta memiliki 3 industri pengolahan susu parteurisasi, merupakan suatu bukti tingginya produksi susu di wilayah Desa Sumogawe tersebut. Populasi responden studi ini adalah anggota dari kelompok tani sapi perah Barokah Abadi (73 orang), namun yang mendapatkan bantuan penguatan pakan ternak hanya sejumlah 43 orang peternak, yakni peternak yang memiliki sapi pada tahap laktasi.

Penelitian menggunakan pendekatan kualitatif. Menurut Bogdan dan Biklen (1992, dalam Rahmat, 2009), penelitian kualitatif bertujuan untuk mendapatkan pemahaman yang sifatnya umum terhadap kenyataan sosial dari perspektif partisipan. Teknik pengambilan data menggunakan metode observasi tidak berstruktur dan wawancara bersifat terbuka kepada informan kunci yang ditetapkan secara purposive yakni dipilih secara sengaja dengan kriteria tertentu. Fakta dan data hasil observasi dan wawancara disimpan dalam bentuk catatan, laporan, dan foto. Informan kunci studi sejumlah 6 orang meliputi petugas
Dinas Peternakan Kabupaten Semarang yang mengetahui tentang latar belakang, tujuan, dan sasaran program penguatan pakan ternak sapi perah; ketua kelompok tani sapi perah penerima program bantuan penguatan pakan sapi perah di Dusun Wates, Desa Sumogawe, Kecamatan Getasan, Kabupaten Semarang, anggota kelompok tani penerima atau yang melaksanakan program, serta anggota kelompok tani yang tidak menerima atau belum melaksanakan program bantuan penguatan pakan ternak. Untuk melengkapi informasi, dicari pula data sekunder yang bersumber dari Dinas Peternakan Kabupaten Semarang.

Analisis data dilakukan dengan metode kualitatif deskriptif. Dimana hasil studi ini dideskripsikan dengan jelas, mencakup deskripsi perencanaan hingga pelaksanaan Program Bantuan Penguatan Pakan Sapi Perah, tingkat partisipasi masyarakat dalam program bantuan tersebut, dan faktor pendorong serta faktor penghambat partisipasi masyarakat dalam Program Bantuan Penguatan Pakan Sapi Perah di Dusun Wates, Desa Sumogawe, Kecamatan Getasan, Kabupaten Semarang.

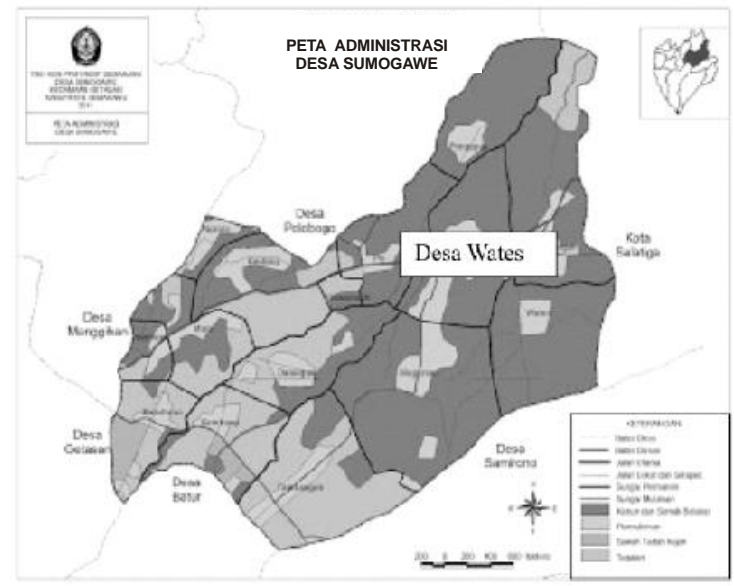

Gambar 1. Peta Desa Sumogawe, Kecamatan Getasan, Kabupaten Semarang

(Sumber: http://sumogawe-getasan.blogspot.com)

\section{HASIL DAN PEMBAHASAN}

\section{Proses Program Bantuan Penguatan Pakan Sapi Perah}

Pelaksanaan Program Bantuan Pakan Ternak di Dusun Wates, Desa Sumogawe, Kecamatan Getasan, Kabupaten Semarang pada tahun 2014 


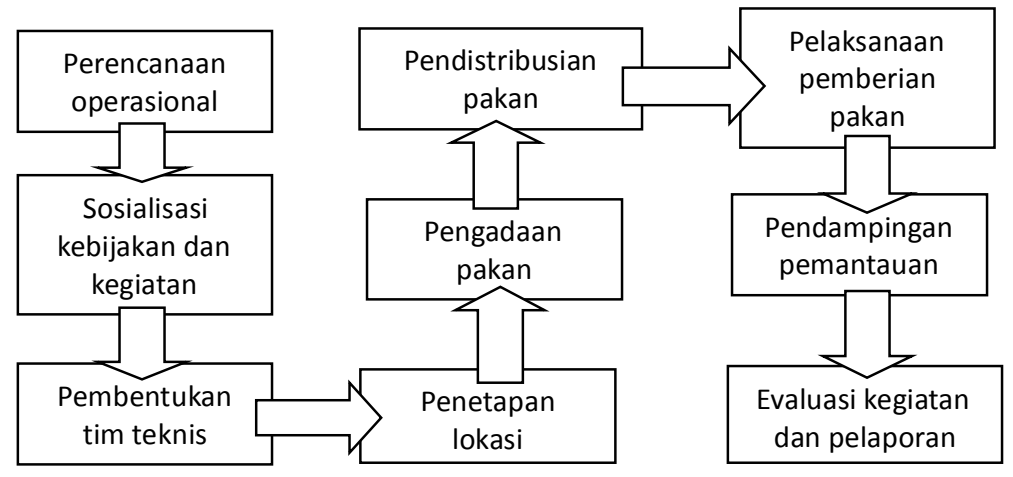

Gambar 2. Tahapan Program penguatan pakan ternak sapi perah

dilaksanakan melalui beberapa tahapan. Tahapantahapan pelaksanaan kegiatan tersebut tampak pada Gambar 2.

Tahap perencanaan operasional merupakan tahap dimana kegiatan bantuan penguatan pakan sapi perah dituangkan di dalam pedoman atau petunjuk pelaksanaan serta petunjuk teknis. Sedangkan pada tahap sosialisasi dilakukan oleh pelaksana pusat dan daerah. Adanya pembentukan tim teknis ditujukan untuk bertugas dan bertanggungjawab terhadap kegiatan, mulai dari proses identifikasi, verifikasi kelompok, mengusulkan lokasi, serta melakukan pendampingan dan pemantauan. Tim teknis itu sendiri terdiri dari petugas lapangan (Petuga Penyuluh Lapangan (PPL) atau mantri tani). Penetapan lokasi peneriman bantuan penguatan pakan ternak ditentukan oleh tim teknis yang telah dibentuk oleh Dinas Peternakan Provinsi Jateng.

Untuk mendapatkan bantuan langsung pakan, kelompok tani susu perah harus memenuhi kriteria yang ditentukan meliputi, 1) Kelompok tani yang sudah terbentuk satu tahun dan terdaftar di Dinas Peternakan Kabupaten/Provinsi; 2) Anggota kelompok mempunyai sapi perah dan menjadi anggota koperasi; 3) Anggota kelompok bersedia menyediakan pakan hijauan; 4) Bersedia dibina dan memberikan laporan setiap 10 hari sekali; 5) Mempunyai struktur organisasi yang lengkap serta pembukuan yang tertib.

Jenis dan jumlah pakan konsentrat yang diberikan kepada peternak yaitu pakan konsentrat sapi perah laktasi dengan kualitas sesuai Standar Nasional Indonesia (SNI), dengan jumlah 2,5 kg/ ekor/hari selama kurang lebih 150 hari. Pakan bantuan ini diberikan khusus kepada sapi perah laktasi dengan jumlah maksimal sapi perah laktasi dalam satu kelompok yang diberikan yaitu 60 ekor. Dalam pelaksanaan program bantuan langsung pakan dinas terkait khususnya petugas lapang berkewajiban untuk membina serta memantau berjalannya program tersebut, apabila dalam pelaksanaan terdapat sesuatu yang tidak sesuai maka akan dikenai sanksi yang sudah ditetapkan oleh perundangan bidang pakan.

Pada tahap pelaporan, baik dinas terkait maupun kelompok tani yang terlibat harus membuat laporan. Kegiatan monitoring dan evaluasi tidak hanya dilakukan pada akhir kegiatan, tetapi merupakan kegiatan yang terus menerus dilakukan. Oleh karena itu kelompok tani setiap 10 hari sekali harus membuat laporan tentang hasil produksi susu di dusunnya sendiri, dan hasil laporan tersebut dikirim ke Dinas Peternakan guna proses evaluasi. Sedangkan Dinas Peternakan Kabupaten Semarang membuat laporan setiap tiga bulan sekali dan mengirimkannya ke Dinas Peternakan Provinsi Jawa Tengah, hal ini dilakukan untuk mengetahui kemajuan kegiatan dan sebagai tolok ukur Direktorat Pakan Ternak untuk penilaian dan keberlanjutan kegiatan di Kabupaten Semarang.

\section{Bentuk Partisipasi Masyarakat}

Tabel 1 menunjukkan bentuk-bentuk keterlibatan masyarakat dalam program penguatan pakan ternak. Partisipasi masyarakat peternak dalam program penguatan pakan tampak pada beberapa tahap. Hasil studi lapang menunjukkan bahwa program bantuan langsung pakan yang diberikan di Dusun Wates, Desa Sumogawe, Kecamatan 
Tabel 1. Keterlibatan Masyarakat dalam Program Bantuan Penguatan Pakan Sapi Perah

\begin{tabular}{|c|c|c|c|}
\hline No. & Tahapan Program & Keterlibatan Masyarakat & Bentuk partisipasi masyarakat \\
\hline 1. & Perencanaan operasional & $\begin{array}{l}\text { Perencanaan oleh pemerintah, tidak } \\
\text { ada keterlibatan masyarakat }\end{array}$ & Tidak ada \\
\hline 2. & $\begin{array}{l}\text { Sosialisasi kebijakan dan } \\
\text { kegiatan }\end{array}$ & $\begin{array}{l}\text { Sosialisasi oleh pemerintah pusat } \\
\text { dan daerah melibatkan ketua-ketua } \\
\text { kelompok tani/ternak atau } \\
\text { perwakilannya }\end{array}$ & Aspirasi masyarakat \\
\hline 3. & Pembentukan tim teknis & $\begin{array}{l}\text { Tim teknis terdiri dari PPL dan } \\
\text { mantri tani setelah menjaring } \\
\text { aspirasi dari wilayah sasaran }\end{array}$ & Aspirasi masyarakat \\
\hline 4. & Penetapan lokasi & $\begin{array}{l}\text { Lokasi program dintentukan oleh } \\
\text { tim teknis }\end{array}$ & Tidak ada \\
\hline 5. & $\begin{array}{l}\text { Pengadaan pakan oleh } \\
\text { pemerintah Provinsi }\end{array}$ & $\begin{array}{l}\text { Pengadaan pakan konsentrat sapi } \\
\text { perah laktasi oleh pemerintah } \\
\text { provinsi }\end{array}$ & Tidak ada \\
\hline 6. & $\begin{array}{l}\text { Pendistribusian ke } \\
\text { peternak }\end{array}$ & $\begin{array}{l}\text { Pendistribusian oleh pemerintah ka- } \\
\text { bupaten/ Dinas Peternakan } \\
\text { Kabupaten }\end{array}$ & Tidak ada \\
\hline 7. & $\begin{array}{l}\text { Pelaksanaan pemberian } \\
\text { pakan }\end{array}$ & $\begin{array}{l}\text { Peternak memberikan } 2,5 \text { kg kon- } \\
\text { sentrat dalam pakan } \\
\text { hijauan/ekor/hari selama kurang } \\
\text { lebih } 150 \text { hari }\end{array}$ & $\begin{array}{l}\text { Penyediaan kandang dan } \\
\text { hijauan pakan serta komitmen } \\
\text { bersama untuk menaati } \\
\text { ketentuan pemberian pakan }\end{array}$ \\
\hline 8. & $\begin{array}{l}\text { Pendampingan dan } \\
\text { pemantauan }\end{array}$ & Pendampingan oleh dinas dan PPL & $\begin{array}{l}\text { Partisipasi sosial saling } \\
\text { mengingatkan antar } \\
\text { masyarakat }\end{array}$ \\
\hline 9. & $\begin{array}{l}\text { Evaluasi kegiatan dan } \\
\text { pelaporan }\end{array}$ & $\begin{array}{l}\text { Evaluasi rutin oleh kelompok tani } \\
\text { tiap } 10 \text { hari membuat laporan }\end{array}$ & $\begin{array}{l}\text { Pelaporan individu dan } \\
\text { kebersamaan/ saling bantu } \\
\text { dalam pembuatan laporan } \\
\text { tertulis }\end{array}$ \\
\hline
\end{tabular}

Getasan berjalan dengan adanya campur tangan dari masyarakat dan anggota dinas terkait, walaupun masih ada beberapa tahap yang masyarakat tidak ikut serta di dalamnya. Sosialisasi dan pertemuan yang dihadiri oleh anggota kelompok tani dan anggota dinas terkait tidak hanya sekedar pertemuan yang bersifat formalitas, namun didalamnya juga terdapat penyampaian aspirasi dan kebutuhan masyarakat yang berasal dari kemauan masyarakat itu sendiri.

Untuk mencapai keinginan yang sesuai dengan kebutuhan masyarakat tidaklah mudah, dibutuhkan beberapa tahap yang harus dilalui, misalnya usulan masyarakat ditampung oleh petugas lapang (PPL) kemudian dari petugas lapang diusulkan ke dinas terkait, begitu selanjutnya disalurkan ke provinsi dan barulah sampai ke pusat. Sampai pada tahap ini usulanpun tidak langsung direalisasikan, perlu dikaji terlebih dahulu.
Mengacu Uphoff dalam Nasution (2009), maka partisipasi masyarakat peterak sapi perah dalam studi ini dapat dikategorikan partisipasi dalam pelaksanaan, memanfaatkan hasil dan penilaian. Bentuk partisipasinya berupa aspirasi dalam penetapan lokasi, tenaga yang diberikan dalam pelaksanaan kegiatan, partisipasi materi berupa pakan hijauan yang diusahakan sendiri untuk dicampur dengan konsentrat bantuan pemerintah, dan partisipasi sosial yakni saling membantu dalam pelaksanaan program, saling mengingatkan dan mengatasi permasalahan bersama. Keterlibatan masyarakat tersebut meningkatkan derajat kepercayaan dan rasa kebersamaan antar masyarakat atas program yang sedang dilakukan. Adanya bantuan program ini juga dijadikan wadah bagi pemerintah maupun masyarakat untuk saling bertukar pikiran dalam perkembangan kegiatan baik yang sudah dilaksanakan maupun yang akan direncanakan. 


\section{Tingkat Partisipasi Masyarakat dalam Program Bantuan Penguatan Pakan Sapi Perah}

Hasil studi lapangan menunjukkan bahwa partisipasi masyarakat tani ternak terhadap program penguatan pakan di Dusun Wates, Desa Sumogawe adalah dalam bentuk tinggal menerima beberapa ketentuan atau degrees of tokenism. Gambar 3 menunjukkan tangga partisipasi yang dicapai masyarakat dalam program penguatan pakan ternak di Dusun Wates, Desa Sumogawe, Kecamatan Getasan, Kabupaten Semarang. Hasil-hasil penelitian sebelumnya didapatkan program yang berawal dari inisiatif pemerintah biasanya masih dalam tahap tokenism.

Tokenism dapat diartikan sebagai kebijakan sekadarnya. Maksudnya berupa upaya supervisial (dangkal, pada permukaan) atau tindakan simbolis dalam pencapaian suatu tujuan. Tindakan tersebut hanya untuk memenuhi persyaratan yang telah ditentukan (oleh pemerintah) sehingga kewajiban telah dilaksanakan (Arsntein, 1969). Penelitian Suroso et al (2014), program musyawarah perencanaan pembangunan desa yang bersifat rutin, didapatkan pada tingkat tokenims, masyarakat tetap didengar dan diperkenankan berpendapat, tetapi mereka tidak memiliki kemampuan untuk mendapatkan jaminan bahwa usulan mereka akan dipertimbangkan oleh pemerintah.

Tingkat partisipasi masyarakat tani ternak terhadap program bantuan langsung pakan sapi perah apabila diposisikan pada delapan anak tangga Arnstein adalah pada anak tangga ke empat yaitu konsultasi. Pada tangga konsultasi ini, dilakukan pertemuan antara pemerintah dengan masyarakat (tahap sosialisasi program), survei tentang aspirasi dan pola pikir masyarakat serta pendapat publik, mengundang aspirasi masyarakat tentang program dan penentuan lokasi program, dan setelah memberikan informasi kepada mereka dilakukan konsultasi yang disertai dengan cara-cara partisipasi yang lain.

Anggota kelompok tani ternak belum sepenuhnya memiliki kekebasan untuk menyampaikan saran dan aspirasi, terlebih dalam pengambilan keputusan. Saran dan pendapat cenderung dapat disampaikan, melalui ketua kelompok tani namun belum tentu dipenuhi dan dilaksanakan. Di samping itu, pada hubungan kekuasaan tokenism ini, anggota kelompok tani ternak masih berada di bawah kontrol dari pemerintah. Meskipun komunikasi telah terjalin antara masyarakat dan pemerintah, namun pengambilan keputusan masih dipegang oleh pemegang kekuasaan (pemerintah) dan masyarakat peternak harus mengikuti ketentuan yang ditetapkan. Pada derajat partisipasi ini, menurut Arnstein (dalam Asjhari, 2013) tingkat keberhasilannya program cenderung akan rendah, karena mengingat tidak adanya jaminan terhadap ide-ide masyarakat.

Dalam studi ini, program belum memperhatikan potensi partsipasi aktif masyarakat. Menurut Basuno et al (2005) partisipasi aktif adalah proses pembentukan kekuatan untuk keluar dari permasalahan yang dihadapi. Dalam kasus program dalam studi ini, masyarakat termasuk dalam partisipasi pasif, yaitu masyarakat dilibatkan dalam

\begin{tabular}{|c|l|}
\hline 8 & Pengawasan Masyarakat \\
\hline 7 & Pendelegasian kekuasaan dan wewenang \\
\hline 6 & Kemitraan/kesetaraan \\
\hline 5 & Kompromi/penentraman \\
\hline 4 & Berkonsultasi \\
\hline 3 & Menginformasikan \\
\hline 2 & Pengobatan dan penyembuhan \\
\hline 1 & Manipulasi \\
\hline
\end{tabular}

Tingkat partisipasi peternak dalam Program Penguatan Pakan

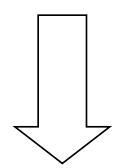

degrees of to kenism

Gambar 3. Tangga Partisipasi Masyarakat dalam Program Penguatan Pakan Ternak di Dusun Wates, Desa Sumogawe, Kecamatan Getasan, Kabupaten Semarang 
tindakan yang telah dipikirkan, dirancang, dan dikontrol oleh orang lain. Masyarakat belum mampu mengatasi penguatan pakan secara mandiri karena teknologi pakan dengan resep khusus tidak bisa disediakan sendiri oleh petani.

\section{Faktor Pendorong dan Faktor Penghambat Partisipasi Masyarakat dalam Program Bantuan Penguatan Pakan Sapi Perah}

Menurut Skilbek (2006) orang dewasa akan berpartisipasi dalam kegiatan pendidikan karena physical factors (contoh; kesempatan berpartisipasi, kecukupan waktu dan kondisi pembelajar), psychological factors (contoh: kepercayaan diri, motivasi untuk belajar), social factors (contoh: dukungan dari keluarga, kelompok, serta pengaturan pembelajaran yang menyenangkan), $e d u-$ cational factors (contoh: relevansi materi, tingkat kesukaran dalam tugas pembelajaran, dan kualitas lingkungan pembelajaran).

Beberapa tinjauan tentang faktor-faktor yang mempengaruhi partisipasi masyarakat antara lain penelitian Baba et al (2011) yang menyatakan bahwa karakteristik peternak yang terdiri dari umur, tingkat pendidikan formal, tingkat kosmopolit dan pengalaman usaha mempengaruhi partisipasi peternak dalam penyuluhan. Egbetokun dan Omonona (2012) menyatakan bahwa faktor utama yang mempengaruhi partisipasi petani antara lain umur, ukuran lahan, selain juga status perkawinan, dan pengalaman usahatani. Hasil observasi dan wawancara dalam studi ini mendapatkan bahwa sebagian besar petani berusia diatas 50 tahun dan berpendidikan SD. Jumlah ternak yang dimiliki sekitar 2 hingga 3 ekor saja, sehingga peternak di Desa Sumogawe termasuk peternak skala kecil. Secara umum anggota kelompok tani ternak bersikap antusias terhadap program penguatan pakan, terutama disebabkan ketertarikan terhadap peningkatan produksi susu dan peningkatan kualitas susu. Usia peternak yang relatif tua dan pendidikan rendah mempengaruhi keterbatasan akses terhadap informasi dan teknologi secara mandiri, sehingga adanya program gratis yang ditawarkan pemerintah tersebut disambut respon positif peternak.
Mengacu hasil wawancara terhadap anggota kelompok tani, baik yang telah melaksanakan maupun yang belum menerima bantuan langsung pakan, serta pendapat dari pegawai dinas terkait yang menangani bantuan program penguatan pakan ternak di Dusun Wates, Desa Sumogawe, Kecamatan Getasan 2014, dapat disimpulkan bahwa faktor yang mendorong masyarakat peternak mau berpartisipasi dalam pelaksanaan Program Bantuan Langsung Pakan yaitu:

1. Bantuan yang diberikan gratis, dan persyaratan yang diperlukan tidak sulit;

2. Program yang dilaksanakan sesuai dengan kebutuhan masyarakat anggota kelompok tani ternak yakni, dapat meningkatkan produksi susu dan diharapkan meningkatkan pendapatan;

3. Petugas lapang/PPL bersedia memberikan pembinaan rutin kepada para anggota kelompok tani ternak;

4. Terjalinnya hubungan kerjasama yang baik antara kelompok tani dengan petugas lapang.

5. Di Dusun Wates tersedia pakan hijauan yang berfungsi sebagai pakan sapi perah selain konsentrat.

Sedangkan faktor-faktor yang dianggap menghambat pelaksanaan program adalah,

1. Beberapa masyarakat yang sudah memiliki pendapatan tinggi tidak mau ikut berpatisipasi karena mereka sudah mampu untuk memberikan pakan ternak dengan kualitas yang baik;

2. Keterbatasan jumlah bantuan mengurangi jumlah peternak yang berpartisipasi dan muncul adanya rasa iri yang timbul dalam anggota kelompok tani karena bantuan yang diberikan hanya untuk 60 sapi laktasi sedangkan jumlah populasi sapi ada lebih dari 60 .

3. Pada Evaluasi yakni adanya perasaan malas pada diri anggota kelompok tani ternak dalam menyusun laporan tertulis hasil produksi susu yang harus dilakukan tiap 10 hari sekali.

Evaluasi kualitatif studi ini tentang faktor pendorong yakni PPL dalam proses partisipasi senada dengan hasil penelitian Yunasaf dan Ginting (2009) yang menyimpulkan bahwa peranan pendamping kelompok tani yakni penyuluh dan keberdayaan kelompok tani berpengaruh positif dan nyata 
terhadap keberdayaan peternak sapi perah. Penyuluh dapat meningkatkan perannya sebagai agen pembaharu, khususnya agar dapat berperan sebagai fasilitator, motivator dan katalisator.

Hubungan yang baik antara ketua kelompok tani ternak dengan PPL juga mendorong adanya program dan partisipasi. Kepemimpinan kelompok yang efektif, tujuan kelompok yang jelas, struktur kelompok yang lengkap, fungsi tugas yang lebih jelas, berjalannya pembinaan dan pemeliharaan kelompok, kekompakan yang kuat, dan suasana kelompok yang kondusif juga mempengaruhi partisipasi anggota kelompok. Hasil tersebut menunjukkan bahwa peternak masih tergantung pendampingan dalam pengembangan kelompok dan juga pengaruh kepemimpinan dalam pengelolaan suatu program.

\section{KESIMPULAN}

Studi ini menyimpulkan beberapa hal yakni:

1. Partisipasi masyarakat peternak dalam program penggiatan pakan sapi perah yang berlangsung di Dusun Wates, Desa Sumogawe, Kecamatan Getasan, Kabupaten Semarang meliputi, keterlibatan dalam tahap sosialisasi kegiatan; tahap pelaksanaan pemberian pakan di kelompok tani; tahap pemantauan; serta evaluasi kegiatan yang diwujudkan dalam pelaporan tertulis oleh peternak.

2. Bentuk partisipasi masyarakat peternak berupa aspirasi dalam penetapan lokasi, tenaga yang diberikan dalam pelaksanaan kegiatan, partisipasi materi berupa pakan hijauan yang diusahakan sendiri untuk dicampur dengan konsentrat bantuan pemerintah, dan partisipasi sosial yakni saling membantu dalam pelaksanaan program, saling mengingatkan dan mengatasi permasalahan bersama.

3. Tingkat partisipasi masyarakat terhadap Program Bantuan Penguatan Pakan Sapi Perah di Dusun Wates, Desa Sumogawe, Kecamatan Getasan, Kabupaten Semarang apabila dibandingkan dengan delapan anak tangga Arnstein hanya sampai pada anak tangga konsultasi, komunikasi telah terjalin antara masyarakat dan pemerintah, namun pengambilan keputusan masih dipegang oleh pemegang kekuasaan (pemerintah) dan masyarakat peternak harus mengikuti ketentuan yang ditetapkan.

4. Faktor pendorong partisipasi masyarakat dalam Program Bantuan Penguatan Pakan Sapi Perah a) Bantuan yang diberikan gratis, dan persyaratan yang diperlukan tidak sulit; b) Program yang dilaksanakan sesuai dengan kebutuhan masyarakat anggota kelompok tani ternak; c) Petugas lapang/PPL bersedia memberikan pembinaan rutin kepada kelompok tani ternak; d) Dusun Wates tersedia pakan hijauan; e) Terjalinnya hubungan kerjasama yang baik antara kelompok tani ternak dengan petugas lapang. Faktor penghambat a) pada tahap evaluasi adanya perasaan malas dalam menyusun laporan hasil produksi susu; b) Pada tahap perencanaan beberapa masyarakat sudah memiliki pendapatan tinggi; dan c) Keterbatasan jumlah bantuan yang menimbulkan rasa iri antar peternak.

\section{UCAPAN TERIMA KASIH}

Penulis mengucapkan terima kasih kepada Nataly Putri, Puji Setiyoko, Yusuf Setyawan, Kaisar Dementoes, atas bantuan pengambilan data.

\section{DAFTAR PUSTAKA}

Asjhari, Ahasan. 2013. Pengukuran Tingkat Partisipasi Masyarakat Desa Ciledug, Kabupaten Bogor dalam Pembangunan Jalan Desa Tipe Otta Seal. Jurnal Sosial Ekonomi Pekerjaan Umum. Vol. 5 No. 2 Juli 2013: 77-85.

Arnstein, Sherry R. 1969. A Ladder of citizen Participation. Journal of the America Institut of Planners, Vol. 35, No. 4, July 1969.http://lithgow-schmidt.dk/ sherryarnstein/ladder-of-citizenparticipation.html diakses 3 Juni 2015.

Baba, S. Isbandi, Totok Mardkanto, Waridin. 2011. Faktor-faktor yang Mempengaruhi Tingkat Partisipasi Peternak Sapi Perah dalam Penyuluhan di Kabupaten Enrekang. Jurnal ITP Vol 1 No. 3 Juli 2011. Hal 193-208.

Basuno, E., R.N. Suhaeti, S. Wahyuni, R.S. Rivai, T. Pranaji, G.S.Budhi, dan M. Iqbal. 2005. Kaji Tindak(Action Research) Pemberdayaan 
Masyarakat di Wilayah Tertinggal. Laporan Penelitian. PusatPenelitian dan Pengembangan Sosial Ekonomi Pertanian. Bogor.

Direktorat Jenderal Peternakan dan Kesehatan Hewan kementrian Pertanian Republik Indonesia. Ditjen PKH. 2013. Pengembangan Pakan Nasional. (http://ditjennak. pertanian. go. id/berita-456-pengembangan-pakannasional.html). Diakses 16 Mei 2015.

Egbetokun, O.A., \& B.T. Omonona 2012. Determinants of Farmers' Participation in Food Market in Ogun State Global. Journal of Science Frontier Research Agriculture and Veterinary Sciences Volume 12 Issue 9 Version 1.0 Year 2012

Nasution, Zulkarnain. 2009. Solidaritas Sosial dan Partisipasi Masyarakat Desa Transisi. UMM Press.
Rahmat, Pupu Saeful. 2009. Penelitian Kualitatif. Jurnal Equilibrium, Vol 5 No. 9 Januari-Juni 2009:1-8.

Skilbeck, M. 2006. Participation in Learning: Why, What, Where and How Do People Learn?. In Lifelong Learning, Participation and Equity, Eds. J. Chapman, P. Chartwright, and E.J. McGilp.

Suroso, H, dkk. 2014. Faktor-faktor yang Mempengaruhi Partisipasi Masyarakat dalam Perencanaan Pembangunan di Desa Banjaran Kecamatan Driyorejo Kabupaten Gresik. Jurnal Wacana Vol.17, no 1:7-15.

Tamba, I Made, I Wayan Cipta. 2011. Analisis Partisipasi Masyarakat dalam Program Pengentasan Kemiskinan Masyarakat Pesisir di Karangasem Bali. Agrimeta. Bali. 